\title{
TITLE:
}

\section{INVERTEBRATE FAUNA OF THE INTERTIDAL ZONE OF THE TOKARA ISLANDS -XII. FORAMINIFERA-}

AUTHOR(S):

Kuwano, Yukio

\section{CITATION:}

Kuwano, Yukio. INVERTEBRATE FAUNA OF THE INTERTIDAL ZONE OF THE TOKARA ISLANDS -XII. FORAMINIFERA-. PUBLICATIONS OF THE SETO MARINE BIOLOGICAL LABORATORY 1956, 5(2): 273-282

ISSUE DATE:

1956-06-30

URL:

http://hdl.handle.net/2433/174552

RIGHT: 


\title{
INVERTEBRATE FAUNA OF THE INTERTIDAL ZONE OF THE TOKARA ISLANDS \\ XII. FORAMINIFERA ${ }^{132)}$
}

\author{
YUKIO KUWANO
}

Research Institute for Natural Resources, Tokyo

With Plates XXVIII-XXX and 1 Text-figure

The foraminiferal materials here discussed are submitted to the writer by Dr. T. Tokioka of the Seto Marine Biological Laboratory, who visited the Tokara Islands, during the period from May 26 to June 12 of 1953, for the biological survey.

As the purpose of this survey and the outline of the results obtained were already described by Dr. T. TokrokA (this journal, III (2), 1953), the writer wishes to give the results of identification of the submitted materials and brief notes on the species distinguished in the following.

The materials treated herein are deposited in the collection of the Seto Marine Biological Laboratory.

\section{On the Occurrence of the Samples}

The submitted materials are divided into two groups according to the mode of occurrence, namely, the reef surface samples and the beach sand sample. The former are composed of the tests attached on the surface of the reef and of the organisms living there, and the latter of the dead tests contained in the beach sand.

The intertidal zone where these samples were collected is clearly divided into four zones characterized by distinct colouration, according to $\mathrm{T}$. TokiokA. The zones are as in the following table (from beach to reef edge).

\begin{tabular}{|c|c|c|c|}
\hline \multirow[b]{2}{*}{ Beach } & Takarazima & \multicolumn{2}{|c|}{ Nakanosima } \\
\hline & Greyish Zone & \multirow{2}{*}{ Rocky Zone } & \multirow[b]{2}{*}{ Yellowish Zone } \\
\hline & Yellowish Zone & & \\
\hline & Purplish Zone & \multicolumn{2}{|c|}{ Purplish Zone } \\
\hline$\stackrel{\downarrow}{\text { Reef edge }}$ & Brownish Zone & \multicolumn{2}{|c|}{ Brownish Zone } \\
\hline
\end{tabular}

1) Scientific Survey of the Tokara Islands, Report No. 23.

2) Contributions from the Research Institute for Natural Resources, No. 771.

Publ. Seto Mar. Biol. Lab., V (2), $1956 . \quad$ (Article 16) 
a) The reef surface samples. These were gathered from the lower half of the intertidal zone, i.e. the part lower than the purplish zone, of Takarazima and Nakanosima.

Among the higher and larger organisms dwelling on the reef surface, two species of foraminifer, which attains to large size, are remarkable. They are described by T. TokIokA as Baculogypsina sphaerulata (PARKER et JONES) and Orbitolites complanata LAMARCK. ${ }^{1)}$ The former is abundantly found on the surface of the reefs and organisms on the reef in Nakanosima (lower than the lower half of the purplish zone). The latter is commonly discovered along the reef edge in Takarazima (brownish zone).

Except these two there is no remarkable, or abundantly occurring foraminifer, that may be distinguished to the naked eye.

b) The beach sand sample. This was collected in Takarazima on the narrow sand beach, which is a part of the yellowish zone, where raised coral reefs eroded to form the deeply excavated cavities, and on the bottom of these cavities the white calcareous sand is deposited to form narrow sand beach or pockets.

This sand is very coarse-grained, and the fraction coarser than $0.59 \mathrm{~mm}$ in diameter attains to over $90 \%$ weight of the whole sample. The grains are from subangular to angular, and are the fragments of calcareous skeletons and shells of such organisms as corals, molluscs and foraminifers. In general, the deposition of coarse-grained calcareous sand seems to be a general feature of the tropical and subtropical beach, the angulosity of grains varies from place to place, being probably affected by minor topographic elements of the beach. . The largeness of angulosity of this sample is probably due to the irregularly eroded and uneven surface of the reef in Takarazima. Therefore, the state of preservation of the foraminiferal tests contained in this sample is fairly well, compared with that recovered from the sand on the flat and open beach.

\section{Results}

The list of the species distinguished is as follows:

The reef surface sample The beach sand sample

Takarazima Nakanosima Takarazima

Textularia sp. - 1

Gaudryina (Siphogaudryina) siphonifera (BRADY) - _ -

Elphidium "crispum" (LINNÉ)

$2 \quad-\quad-$

Heterostegina depressa D'ORBIGNY

Heterostegina suborbicularis (LAMARCK)

Heterostegina cf. suborbicularis (LAMARCK)

$-7$

$\begin{array}{lll}1 & - & 1\end{array}$

Peneroplis pertusus (FORSKÅ)

$1 \quad 1$

Amphisorus hemprichii EHRENBERG

- $\quad-\quad 3$

1) Orbitolites complanata LAMARCK of TOKIOKA=Marginopora vertebralis BLAINVILLE. 


$\begin{array}{lccc}\text { Marginopora vertebralis BLAINVILLE } & 42\left(+4^{*}\right) & 4 & 52^{*}(11.0 \%) \\ \text { Borelis sp. } & - & - & 1 \\ \text { Rotalia beccarii (LiNNÉ) var. } & - & - & 3 \\ \begin{array}{l}\text { Eponides (Poroeponides) concameratus } \\ \quad \text { MonTAGU) var. }\end{array} & - & - & 9 \\ \text { Amphistegina radiata (FICHTEL et MOLL) } & 35 & 16 & 53 \\ \text { Amphistegina sp.** } & 6 & 9 & 62 \\ \text { Calcarina defrancii D'ORBIGNY } & 4 & 47 & 67(14.1 \%) \\ \text { Calcarina cf. hispida BRADY } & - & 1 & - \\ \text { Baculogypsina sphaerulata (PARKER et JONES) } & 61 & \text { ca. } 800 & 133(27.9 \%) \\ \text { Cymbaloporetta bradyi (CUSHMAN) } & - & - & 2 \\ \text { Gypsina? sp. } & - & - & 5 \\ \text { Planorbulinella larvata (PARKER et JoNES) } & - & - & 7 \\ \text { Homotrema rubrum (LAMARCK) } & - & - & 25^{*} \\ \text { Gen. et sp. indet. } & - & - & 16\end{array}$

Total 474 indiv.

* Fragments.

** Probably could be referred to A. radiata.

a) The reef surface samples. As the collection of these samples are not so precisely designed, the results listed above do not necessarily represent the specific composition of the living assemblages on the reefs of these islands. However, they are sufficient for us to conclude on the general character of this assemblages of these islands. The predominant species, Baculogypsina sphaerulata (PARKER et JoNES) and the species associated with it, i.e. Amphistegina radiata, Marginopora vertebralis, Calcarina defrancii, are the tropical and subtropical species, commonly found in the shallow waters of the Indo-Pacific Region.

b) The beach sand sample. The death assemblage contained in this sample, is characterized as Baculogysina sphaerulata-Amphistegina radiata-Calcarina defrancii Assemblage. The specific composition is quite similar to that of the reef surface sample in Nakanoshima, except that Baculogypsina sphaerulata is so far abundant than the other species in the latter, that we might call it as Baculogypsina sphaerulata Assemblage. However, whether the specific composition of these two assemblages represents the same fauna or not, remains as a question, until more detailed investigations will touch this point.

\section{Comparison with the Data Hitherto Known}

The foraminiferal assemblages of intertidal zone in the Tokara Islands are evidently of tropical and subtropical nature, as already stated. Therefore, our attentions should be called to the comparisons with the intertidal assemblages from the more northern waters. 
On the Pacific side of Japan, most of the tropical and subtropical species found from the Tokara Islands occur fairly rich in Kannoura, Sikoku (AsANo, 1937). There the beach sand contains such tropical and subtropical species as Amphistegina radiata, Calcarina spengleri (abundant), Marginopora vertebralis, Rotalia calcar, Calcarina mayori, Miniacina miniacea (common), and Heterostegina depressa (rare). However, with these species are found many miliolid species, which are common in the warm waters around Japan. These miliolids are the principal constituents of the shallow water assemblages of middle Honsyû together with many species belonging to the other genera. For example, Elphidium "crispum," Cibicides refulgens, and several species of the genus Textularia.

From Sikoku to northward, the tropical and subtropical elements suddenly decrease in number of species and individuals. In the Ago Bay, no tropical and subtropical species except Amphistegina radiata and Marginopora vertebralis is found, and all the other species occurring there are the elements of warm water assemblages (MORISHIMA, 1948, 1950). Here Amphistegina radiata is one of the principal constituents of Amphistgina-Elphidium crispum Assemblage, and its frequency of occurrence attains to 20-30\%. But Marginopora vertebralis is found in lower frequency (less than $5 \%$ ). In the bay mouth area of the Tokyo Bay, only few individuals of Amphistegina radiata are found and the occurrence of Marginopora is not hitherto known (Kuwano, MS). The writer supposes that the northern limit of Amphistegina radiata is to be lined just north off the Bôsô Peninsula.

It is hitherto known that the beach sand assemblge from Hatizyôzima contains several tropical and subtropical species as follows: Amphistegina radiata, Amphisorus hemprichii, Heterostegina depressa, Peneroplis pertusus, Planorbulinella larvata, and Gaudryina (Siphogaudryina) siphonifera (Uchro, 1952). However, except Amphistegina radiata, the frequency of occurrence of these species is lower than that of the representatives of the miliolids, the genera Textularia, Discorbis, etc.

On the Japan Sea side of Japan, Amphistegina radiata and Marginopora vertebralis are found from the Obama Bay (Morishima, 1948, 1950). The distribution pattern of these two species are quite similar as in the Ago Bay. Judging from the previously published data, the distribution area of them does not extend to the more northern waters off Niigata Prefecture (OINomrkado and STACH, 1948).

On the basis of these comparisons, it can be safely concluded that any assemblage, which is equivalent to that of the Tokara Islands, is not present in the shallow waters around middle Honsyû and that the tropical and subtropical elements completely disappear off the middle part of Honsyû.

It is evident that the above-mentioned differences between several assemblages are caused by different ecological factors in the areas concerned. However it seems that these differences are more complicated by the presence of the other factors. For example, the examination of the intertidal material collected in Okinoerabuzima reveals somewhat different aspects as to the foraminiferal fauna. This material was recovered 
from the surface of a bivalved molluscan shell dwelling in the tide pool on the reef surface in Okinoerabuzima, where the similar climatic factors probably governs, though this island is situated geographically more south than the Tokara Islands. The principal constituents of the Okinoerabu assemblage are the representatives of the genera Amphistegina, Calcarina (fairly rich in individual numbers), Discorbis, Discopulvinulina, Cibicides, Entosolenia, Buliminella and Bolivina (rich in individual numbers and number of species). And such dominant species in the Tokara Islends as Baculogypsina sphaerulata and Marginopora vertebralis decrease much in individual numbers. Besides, this assemblage is composed of the foraminiferal tests varying considerably in the size of test, while the reef surface assemblage from the Tokara Islands is chiefly composed of the tests of fairly large size.

The writer considers that the catse of these differences should be left as a problem, until more detailed survey will be carried out in the future. However, the difference of the sampling method (as to the reef surface samples), and the difference of the mechanical sorting of shore sand by waves (as to the beach sand sample) are temporarily suggested.

\section{Notes on the Species \\ Gaudryina (Siphogaudryina) siphonifera (BRADY)}

(Pl. XXVIII, Figs. 1-3)

The northern limit of distribution in Japan: Tokyo Bay, bay mouth area (Kuwano, MS). Recorded from off the Ryûkyô Islands (Hanzawa, 1928); and Hatizyôzima, beach sand, less than $0.1 \%$ (Uchio, 1952). TK. Nos. 502-503.

\section{Heterostegina depressa D'ORBIGNY \\ (P1. XXVIII, Figs. 4-7)}

The northern limit of distribution in Japan: Kannoura, Sikoku, beach sand (AsAno, 1937). Recorded from off the Ryûkyû Islands (HanzawA, 1928); and Hatizyôzima, beach sand, 0.1-1.0\% (UChIO, 1952). TK. Nos. 505-508.

\section{Heterostegina suborbicularis (LAMARCK)}

(P1. XXVIII, Figs. 8, 9)

Newly recorded from the Japanese waters. TK. Nos. 509, 509 a.

\section{Peneroplis pertusus (FORSKÅL)}

The northern limit of distribution in Japan: Koaziro, Miura Peninsula, beach sand, 
rare (Peneroplis sp.) (HIGuchr, 1954). Recorded from the coast of Ryakyya (YABE and Hanzawa, 1925). TK. No. 511.

\section{Amphisorus hemprichii EHRENBERG}

The northern limit of distribution in Japan : Hatizyôzima, beach sand, 1-5\% (UCHIo, 1952). Recorded from the coast of Ryûkyû (YABE and HANZAwA, 1925); and off Ryûkyûu (Hanzawa, 1928). TK. 512.

\section{Marginopora vertebralis BLAINvILLE}

(Pl. XXVIII, Figs. 10-17)

The northern limit of distribution in Japan: Ago Bay, the middle part, less than 5\% (Morishima, 1950). Recorded from Kannora, Sikoku, beach sand (Asano 1937). TK. Nos. 513-519, 530.

Eponides (Poroeponides) concameratus (MonTAGU) var.

(P1. XXIX, Figs. 2, 3)

TK. Nos, 522-523.

\section{Amphistegina radiata (FICHTEL et MoLL)}

(P1. XXIX, Figs. 4-9)

In the adult individuals, the form of test widely varies from biconvex to planoconvex, and the forms of sutures from deeply meandered to simple. The convexity of of the test increases as the test grows.

The northern limit of distribution in Japan: Tokyo Bay, bay mouth area (KuwANo, MS). Recorded from the coast of the Ryûkyû Islands (YABE and HANZAwA, 1925); off Ryûkyû (Hanzawa, 1928); Tanegasima (Hanzawa, 1935); Kannoura, Sikoku (Asano, 1937) ; Tanabe Bay (Morishima, 1950) ; Ago Bay, bay mouth area, 20-30\% (Morishima, 1950) ; Sagami Bay (Asano, 1937) ; Hatizyôzima, beach sand, 15-20\% (Uchio, 1952) ; Obama Bay, bay mouth area, 10\% (Morishima, 1948); Wakasa Bay (Asano, 1937). TK. Nos. 524-529.

\section{Calcarina defrancii D'ORBIGNY}

(Pl. XXIX, Figs. 10-14)

Newly recorded from the Japanese waters. TK. Nos. 534-541.

\section{Calcarina cf. hispida BRADY}

(P1. XXX, Figs. 1-3)

Recorded from off the Ryûkyû Islands (Calcarina hispida Bradx) (Hanzawa, 
1928). TK. No. 542.

\section{Baculogypsina sphaerulata (PARKER et JONES)}

(PI. XXX, Figs. 4-9; Text-fig. 1)

Among a number of individuals of this species from Nakanosima (the reef surface sample), a few specimens with remarkably different surface ornamentation are found. The outer wall of the test like bubbles and no papillae is present on the surface of it. Some of the radial spines do not extend in the plane of coiling (along the equatorial plane of the test), hence the normal, radial arrangement of the spines are irregularly

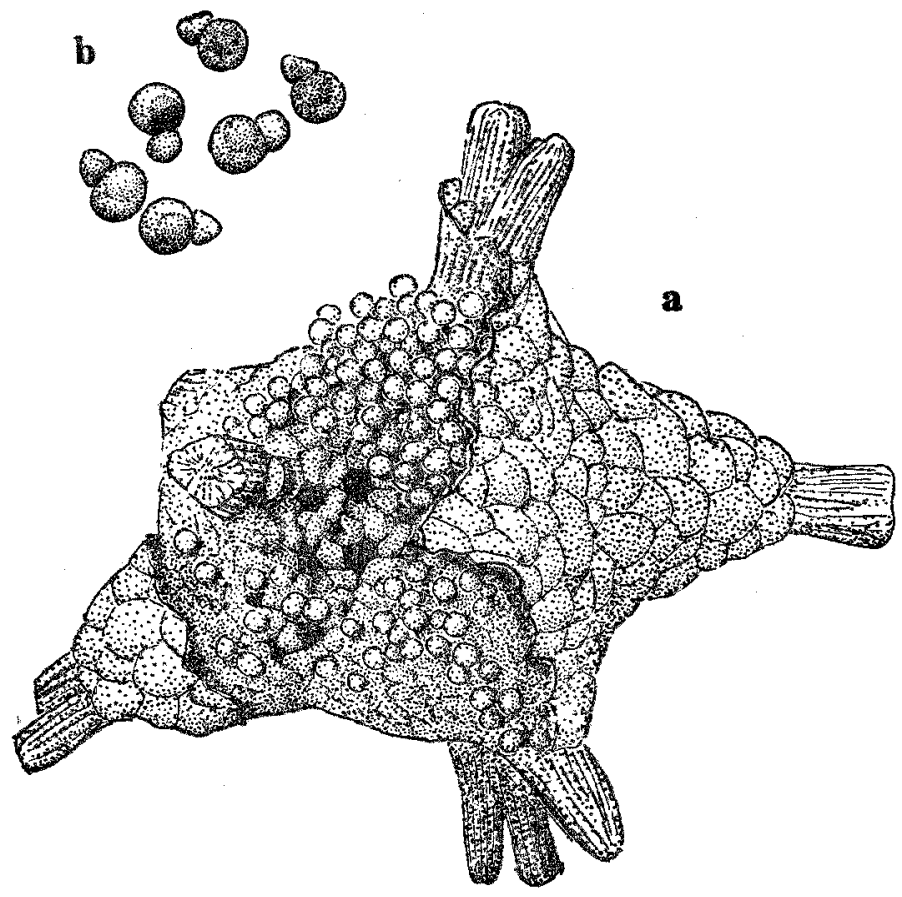

Fig. 1. Baculogypsina sphaerulata (PARKER et JONES). $a$, A parental test containing the young organisms, the outermost wall partially broken. Max. diam. (including spines), $2.7 \mathrm{~mm}$. Nakanosima, reef surface. $b$, Two chambered young organisms. Magnified about 80 times.

modified. The spines of these individuals are irregularly doubled, or sometimes represented by groups of small processes, 4-6 in number (Pl. XXX, Fig. 9). Among them one individual which contains a number of two-chambered young just inside the outermost wall is found (Text-fig, 1a, b). These young individuals are found in the chamber formed between the outermost wall and the inner wall. On the surface of the inner wall, several papillae are observed. They are arranged a little coarser than 
those of the normal individuals and are larger in size. Considering from the fact that among a number of individuals with normal ornamentation from Nakanosima and Takarazima, individuals with somewhat coarser arranged papillae are rather commonly found (PI. XXX, Fig. 7), the above-mentioned individual with young organisms represents the representative of the same species as a number of individuals with normal ornamentation. The presence of the young individuals in the parental test suggests that this individual is an agamont, and collected just after the schizogony, and that this species has the same reproductive process as in Iridia serialis, which also forms young organisms inside the parental test, in so far as the agamont generation is concerned.

The northern limit of distribution in Japan: Tanegasima (HANZAwA, 1935). TK. Nos. 543-552.

\section{Cymbaloporetta bradyi (CushmaN)}

(Pl. XXX, Figs. 10, 11)

The northern limit of distribution in Japan: off Kusiro, Hokkaido (TakayanagI, 1953). Recorded from Zusi and Koaziro, Miura Peninsula, beach sand (HrGuchI, 1954); Siogama Bay (Asano, 1937); off Isizi, Niigata Prefecture (OInomikado and STACH, 1948). TK. Nos. 553-554.

\section{Planorbulinella larvata (PARKER et JONES)}

(Pl. XXX, Figs. 12, 13)

The northern limit of distribution in Japan; Hatizyôzima, beach sand, less than $0.1 \%$ (Uchio, 1952). Recorded from off the Ryukyu Islands (Hanzawa, 1928). TK. Nos. 556-557.

\section{Homotrema rubrum (LAMARCK)}

TK. No. 558.

\section{Acknowledgment}

The writer expresses his cordial thanks to Dr. T. TokıokA, who kindly give the opportunity to examine the material collected by him during the Tokara Scientific Expedition. 


\section{REFERENCES}

Asano, K. 1937. A comparion of the Recent Foraminifera from Tosa Bay and the Pliocene Foraminifera from Aki-gun, Province Tosa. Journ. Geol. Soc. Japan, 44 (520), pp. 36-55. 1937. Foraminifera from Siogama Bay, Miyagi Prefecture, Japan. Saitô Hô-on Kai Museum, Res. Bull. No. 13, pp. 109-119.

CUshman, J. A. 1910-1916. A Monograph of the Foraminifera of the North Pacific Ocean. U. S. Nat. Mus., Bull. 71, 596 pp.

Hanzawa, S. 1928. Preliminary report on marine deposits from the southwestern North Pacific Ocean. Rec. Oceanogr. Wks. in Japan, 1 (2), pp. 59-77.

1935. Topography and Geology of the Riukiu Islands. Sci. Rep. Tôhoku Imp. Univ., Ser. 2 (Geol.), 17, pp. 1-61.

HiguchI, Y. 1954. Fossil Foraminifera from the Miyata Formation, Miura Peninsula, Kanagawa Prefecture. Journ. Geol. Soc. Japan, 60 (703), pp. 138-144.

Morishima, M. 1948. On the accumulations of foraminiferal tests in Obama and Maizuru Bays. Physiol. \& Ecol., 2 (3/4), pp. 42-58. (In Japanese with English résumé)

1950. Accumulation of foraminiferal tests in Ago Bay (Studies on the pearl fishery ground of the Ago Bay, IV). Cont. to Physiol. \& Ecol., Kyoto Univ., No. 72, pp. 6266. (In Japanese)

OrNomikado, T. \& STACH, L. W. 1948. Recent shallow water foraminiferal assemblages from Niigata Prefecture, Japan. Rep. Committ. Treat. Mar. Ecol. Paleoecol., No. 8, 1947-1948. National Research Council, Washington, D. C., pp. 104-110.

TokiokA, T. 1953. Invertebrate fauna of the intertidal zone of the Tokara Islands. I. Introductory notes, with the outline of the shore and the fauna. Publ. Seto Mar. Biol. Lab., 3 (2), pp. 123-137.

UCHIO, T. 1952. Foraminiferal assemblage from the Hachijo Island, Tokyo Prefecture, with description of some new genera and species. Jap. Journ. Geol. Geogr., 22, pp. 145-159.

YABE, H. \& HANZAWA, S. 1925. Globigerina ooze from the sea lying south of Okinawa-jima (Riukiu Islands). Jap. Journ. Geol. Geogr., 4 (1/2), pp. 47-54.

\section{EXPLANATION OF PLATES XXVIII-XXX}

\section{Plate XXVIII}

Figs. 1-3. Gaudryina (Siphogaudryina) siphonifera (BRADY).

Takarazima, beach sand. Length, $1.3 \mathrm{~mm}$.

Figs. 4-7. Heterostegina depressa D'OrBIGNy.

Nakanoshima, reef surface.

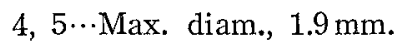

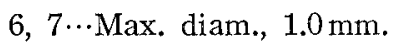

Figs. 8, 9. Heterostegina suborbicularis (LAMARCK).

Takarazima, beach sand. Max. diam., $2.0 \mathrm{~mm}$.

Figs. 10-17. Marginopora vertebralis Blainville.

Takarazima, reef surface. (11-13, inner structure; $14-17$, aperture)

$10 \cdots$ A test of small size, diam., $4.1 \mathrm{~mm}$.

$11,12 \cdots$ A test of fairly large size, diam., $9.0 \mathrm{~mm}$.

11--Peripheral part.

12-Near the center of the test.

$13 \cdots \mathrm{A}$ test of small size, diam., $4.0 \mathrm{~mm}$, thickness, $0.2 \mathrm{~mm}$. 
$14 \cdots$ A test of large size, diam., $10.0 \mathrm{~mm}$, thickness, $0.7 \mathrm{~mm}$.

$15 \cdots$ A test of small size, diam., $3.0 \mathrm{~mm}$, thickness, $0.3 \mathrm{~mm}$.

$16 \cdots$ The same test as Fig. 10, thickness, $0.3 \mathrm{~mm}$.

$17 \cdots$ A test of very small size.

$(1,4,6,8,10$-side view; 2 -apertural v. ; 3 -view from the apical end ; $5,7,9,14,15,16$, 17-peripheral v.; 11, 12, 13-section)

\section{Plate XXIX}

Fig. 1. Borelis sp. Width, $0.7 \mathrm{~mm}$. Takarazima, beach sand.

Figs. 2, 3. Eponides (Poroeponides) concameratus (MonTaGU) var.

Takarazima, beach sand. Max. diam., $1.2 \mathrm{~mm}$.

Figs. 4-9. Amphistegina radiata (FICHTEL et MOLL)

$4,5,6 \cdots$ A well-developed, biconvex test with deeply meandered sutures.

Takarazima, reef surface. Max. diam., $1.6 \mathrm{~mm}$.

$7,8 \cdots \mathrm{A}$ test of small size. Thin lenticular form with simple ornamentation.

Nakanosima, reef surface. Max. diam., $0.9 \mathrm{~mm}$.

$9 \cdots$ A test of small size, with a lip-like projection along the aperture. Takarazima, reef surface. Height of the apertural face, $0.2 \mathrm{~mm}$.

Figs. 10-14. Calcarina defrancii D'ORBIGNY

Nakanosima, reef surface.

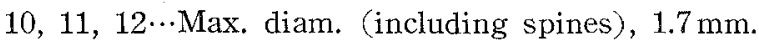

$13 \cdots$ A test of small size, max. diam., $1.1 \mathrm{~mm}$.

$14 \cdots$ Showing the arrangement of the chambers and spines. Max. diam., $1.5 \mathrm{~mm}$.

(1,9-apertural view ; $2,4,7,11,14$-dorsal v. ; 3, 5, 8, 10-ventral v.; $6,12,13$-peripheral v.)

\section{Plate XXX}

Figs. 1-3. Calcarina cf. hispida BRADY Nakanosima, reef surface.

Max. diam., $1.8 \mathrm{~mm}$.

Figs. 4-9. Baculogypsina sphaerulata (PARKER et JONES)

4, $5 \cdots$ Nakanosima, reef surface. Max. diam., $2.2 \mathrm{~mm}$.

6 ... Ornamentation coarser than the normal state. Takarazima, reef surface.

Magnification same as Figs. 4, 7 and 8.

$7 \cdots$ Ornamentation shown by breaking the outermost wall of the test, in which the schizogonical processes are prepared. Nakanosima, reef surface.

8*Bubble-like surface ornamentation without papillae. Nakanosima reef surface.

9 ...Double and irregularly divided spines on the test, in which the schizogonical processes are probably prepared. Nakanosima, reef surface. Magnified about about 29 times.

Figs. 10, 11. Cymbaloporetta bradyi (Cushman).

Takarazima, beach sand. Max. diam., $0.6 \mathrm{~mm}$.

Figs. 12, 13. Planorbulinella larvata (PARKER et JONES).

Takarazima, beach sand. Diam., $1.6 \mathrm{~mm}$.

(1, 10-ventral view; 2, 11-dorsal v.; 3, 5, 13-peripheral v.; 4,9,12-side v.; 6, 7, 8, 9-surface ornamentation) 
Publ. Seto Mar. Biol. Lab. V, 2 (1956)

PLATE XXVIII
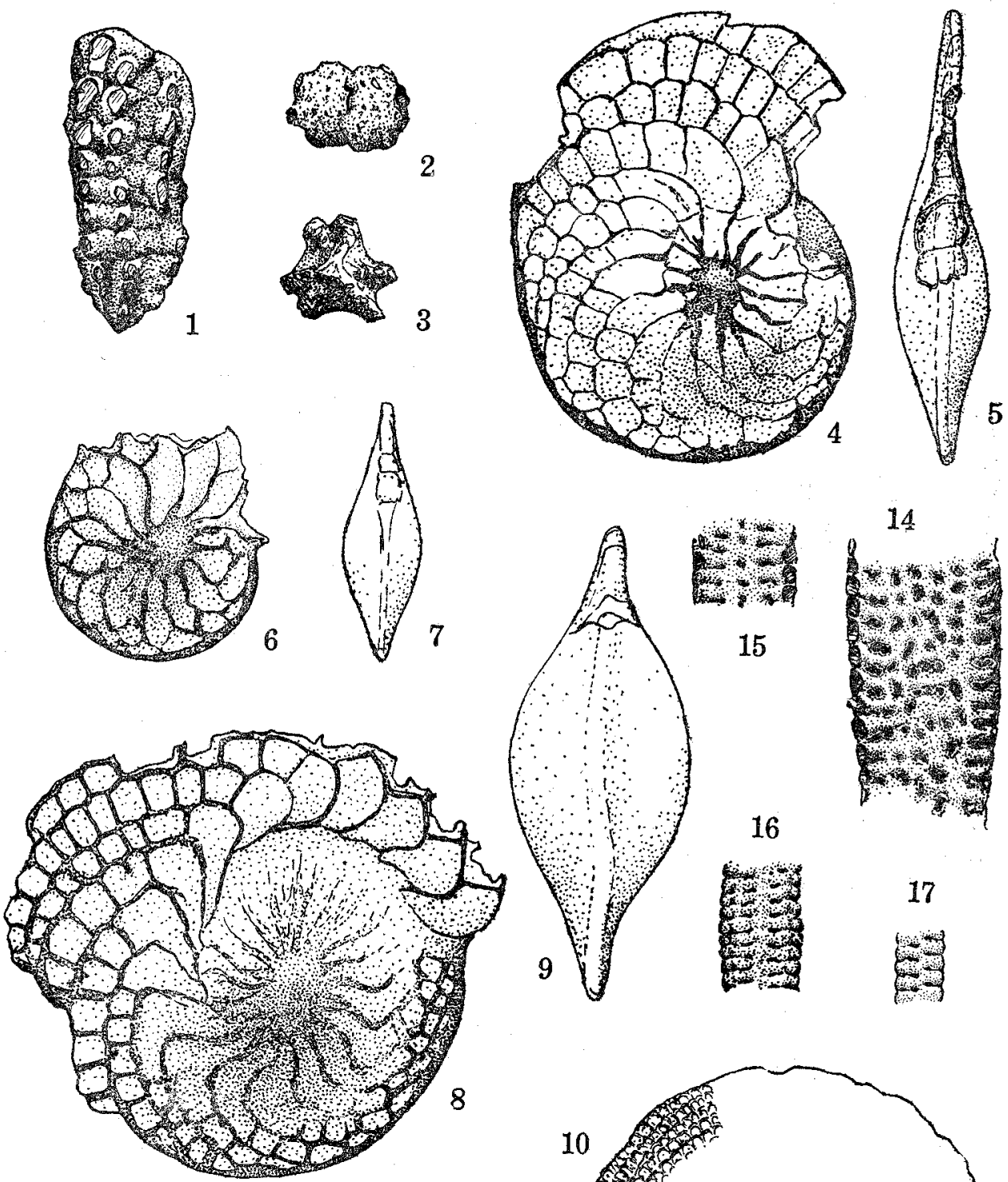

16

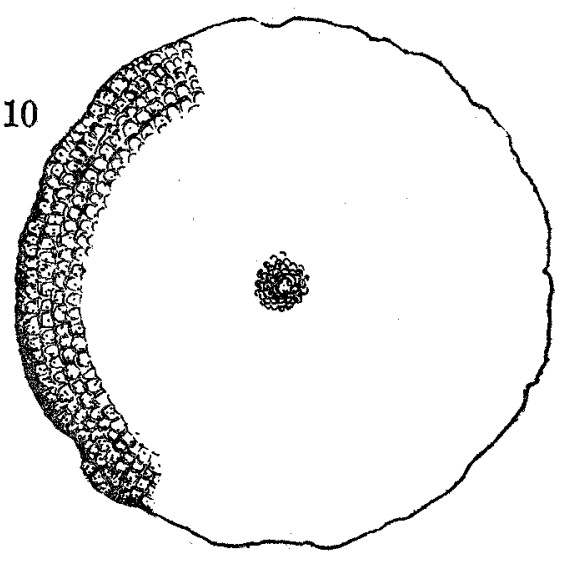

Y. Kuwano: Invertebrate Fauna of the Tokara Islands, XII. 
Publ. Seto Mar. Blol. Lab. V, 2 (1956)
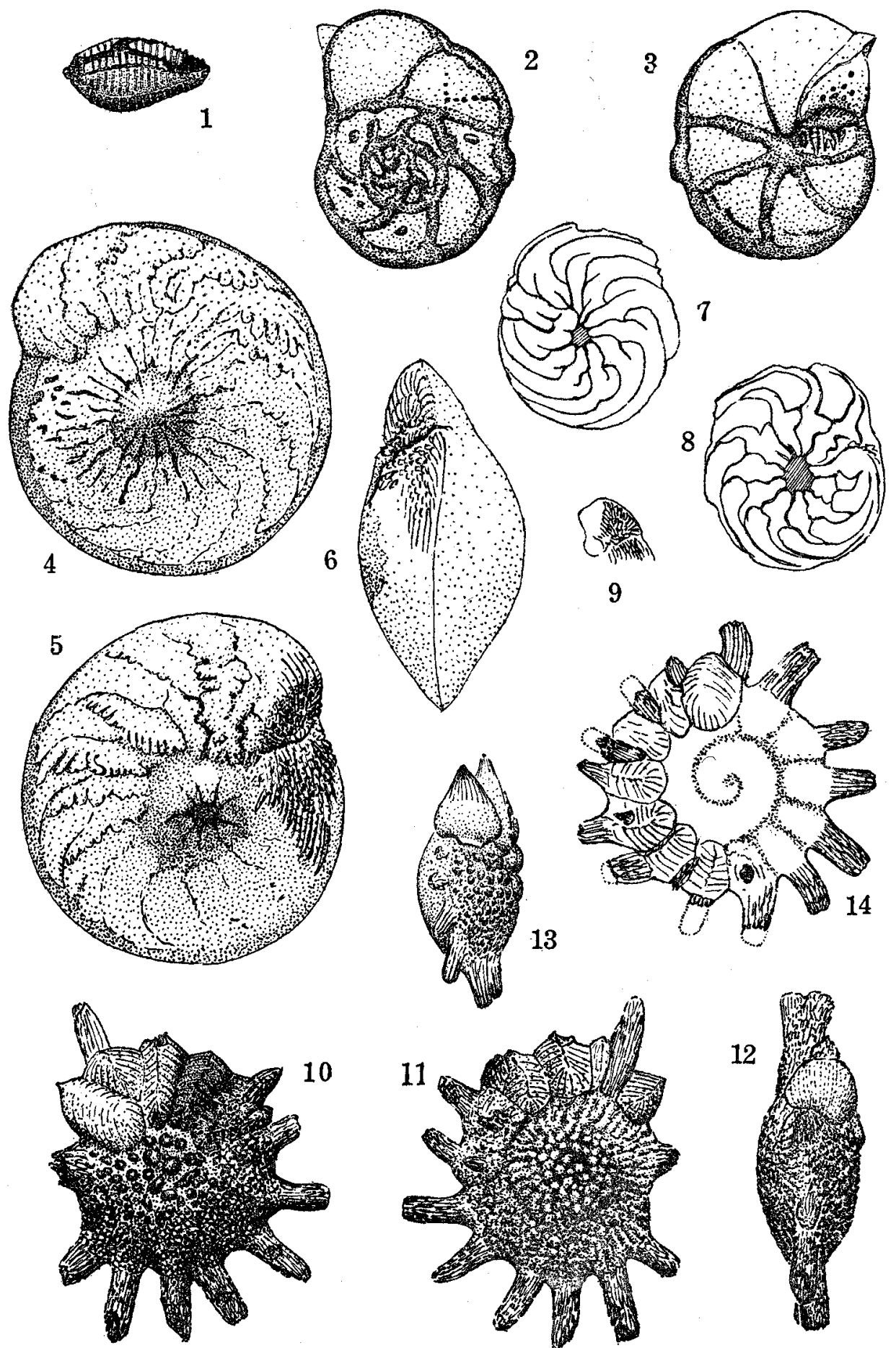

9

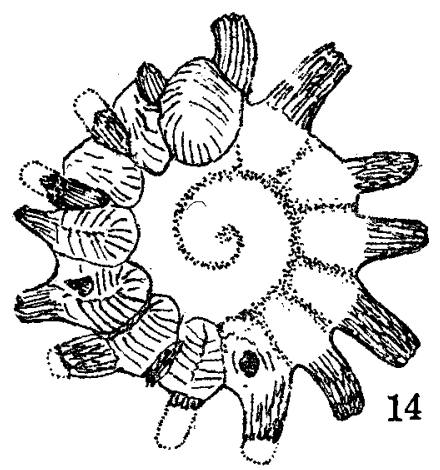

Y. Kuwano: Invertebrate Fauna of the Tokara Islands, XII. 
Publ. Seto Mar. Biol. Lab. V, 2 (1956)

PLATE XXX
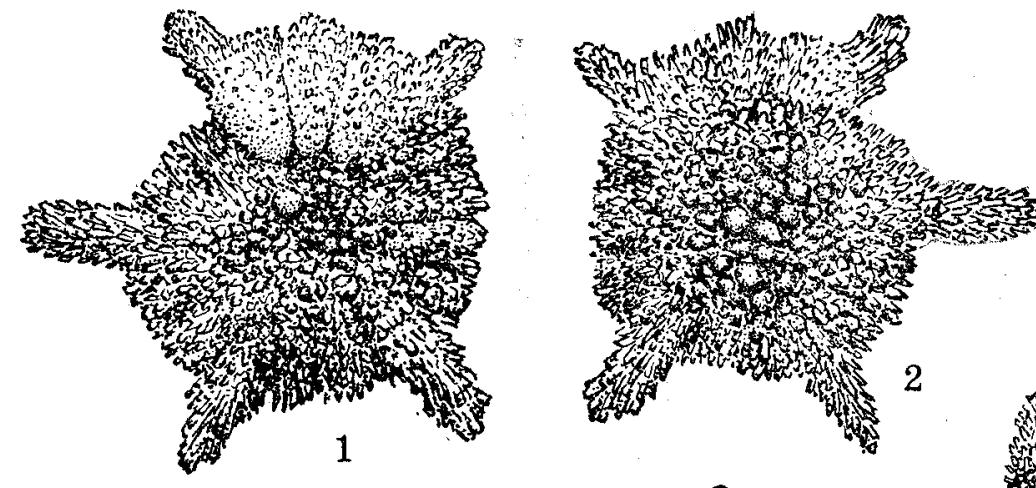
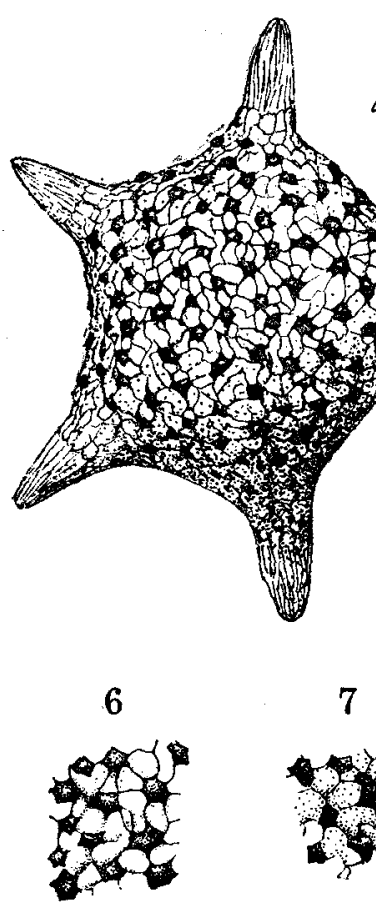

10

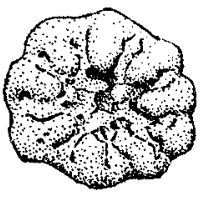

11

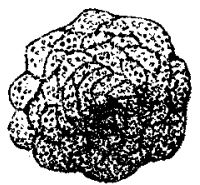

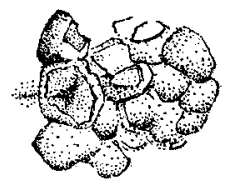

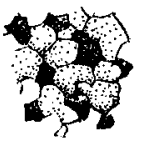

12
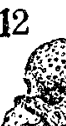
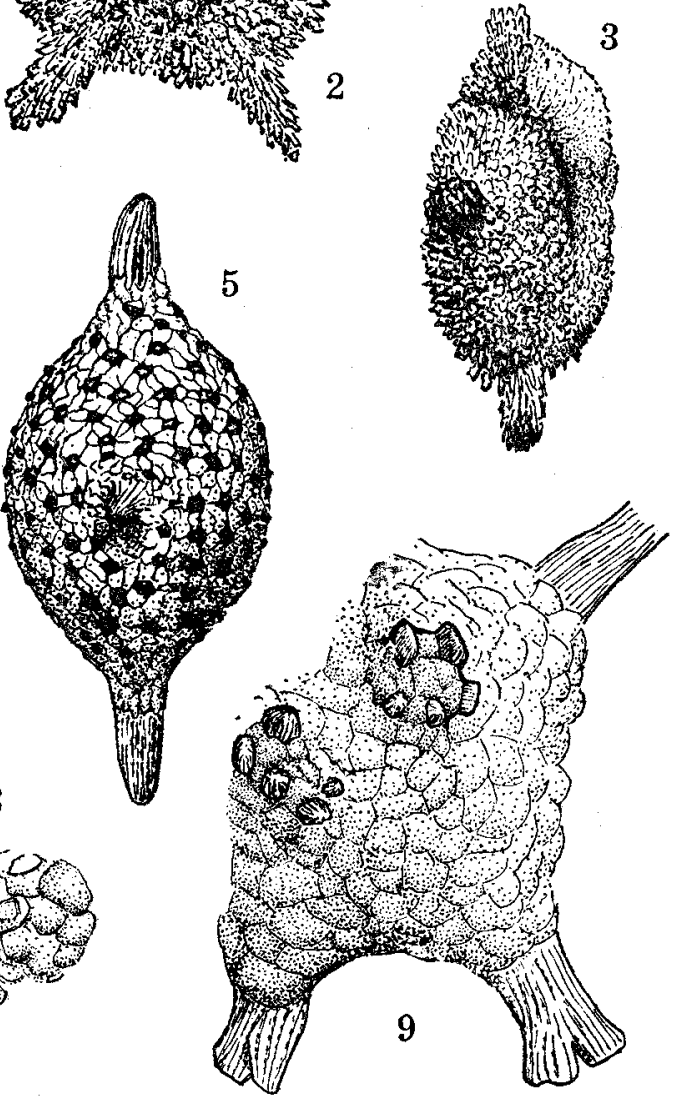

$4 \times 3)^{3} \times$ isto

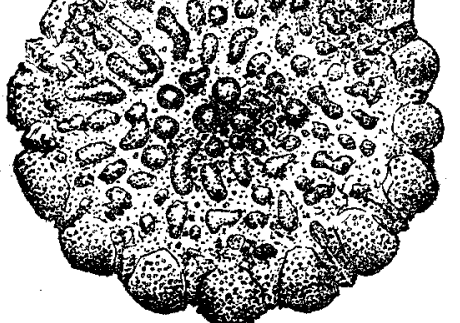

13

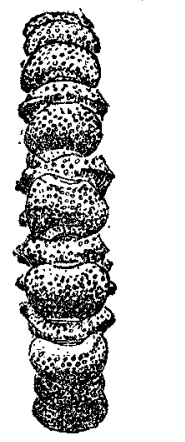

Y. Kuwano: Invertebrate Fauna of the Tokara ISlands, XII. 